\title{
Article \\ Exploratory Factor Analysis of Rainbow Trout Serum Chemistry Variables
}

\author{
Maurizio Manera
}

Citation: Manera, M. Exploratory Factor Analysis of Rainbow Trout Serum Chemistry Variables. Int. J. Environ. Res. Public Health 2021, 18, 1537. https://doi.org/10.3390/ ijerph18041537

Academic Editors: Daniela Varrica and William Toscano

Received: 8 December 2020

Accepted: 3 February 2021

Published: 5 February 202

Publisher's Note: MDPI stays neutral with regard to jurisdictional claims in published maps and institutional affiliations.

Copyright: (C) 2021 by the author. Licensee MDPI, Basel, Switzerland. This article is an open access article distributed under the terms and conditions of the Creative Commons Attribution (CC BY) license (https:// creativecommons.org/licenses/by/ $4.0 /$ )
Faculty of Biosciences, Food and Environmental Technologies, University of Teramo, St. R. Balzarini 1, 64100 Teramo, Italy; mmanera@unite.it; Tel.: +39-0861-266980

\begin{abstract}
Clinical chemistry offers a valuable, affordable, moderately invasive, and nondisruptive way to assess animal physiological status and wellness within defined ranges and is widely used as a diagnostic clinical tool. Because of physiological differences between mammals, clinical correlates of blood chemistry variables are not known in detail in fish, in which tissue/organ function tests are inferred from mammal-derived clinical chemistry data. The aim of the present study was to apply exploratory factor analysis on a serum chemistry dataset from clinically healthy, reared rainbow trout Oncorhynchus mykiss (Walbaum, 1792) to select the most correlated variables and to test for possible underlying factors explaining the observed correlations as possible physiological status estimates in trout. The obtained factors were tested for correlation with hepatosomatic and splenosomatic indexes. Thirteen highly correlated variables were selected out of 18 original serum chemistry variables, and three underlying factors (Factors 1, 2, and 3) were identified that explained the observed correlations among variables. Moreover, Factor 1 correlated negatively with the hepatosomatic index and Factors 2 and 3 negatively with the splenosomatic index. The obtained factors were tentatively associated with: protein (liver) metabolism (Factor 1), cell turnover (Factor 2), and lipid (muscle) metabolism (Factor 3).
\end{abstract}

Keywords: exploratory multivariate analysis; fish wellness; fish physiology; fish biochemistry

\section{Introduction}

Clinical chemistry offers a valuable, affordable, moderately invasive, and nondisruptive way to assess animal physiological status and wellness within defined ranges and is widely used as a diagnostic clinical tool [1]. With regard to fish, problems arise regarding the definition of normal ranges because of the possible influence of many internal and external environmental factors [2-4]. Moreover, and as a result of physiological differences between fish and mammals, from which clinical chemistry methods have been developed, clinical correlates of blood chemistry variables are not known in detail. For instance, and generally speaking, fish are ammonotelic animals relying on gills for nitrogenous waste clearance, whereas mammals are ureotelic animals, excreting nitrogenous waste mainly in the form of urea through the kidney [5-7]. In fish, kidney functionality relies on evolutionary consideration related to the environment in which each single species has evolved [8,9]. Therefore, blood chemistry variables in fish may account for different and not completely understood morphofunctional and pathophysiological features and may correlate differently with each other. As a clinical chemistry routine in human and veterinary medicine, more than one variable is used to assess tissue/organ functionality. These markers of tissue/organ functionality are selected based on possible physiological and/or pathophysiological correlations among the chosen variables. As a consequence, there are, e.g., liver function and kidney function tests $[1,10,11]$. To date, this is not the case in fish, where tissue/organ function tests are inferred from mammal-derived clinical chemistry data, therefore deserving further research. Fish farming has dramatically increased over recent years, with fish being widely used for human and animal nutrition, in 
environmental and biomedical research [12-14]. As a result, there is an urgent, mandatory need to define fish physiological status and wellness criteria to be applied in accordance with regulations in force worldwide [12].

The aim of the present study was to apply exploratory factor analysis on a serum chemistry (normal ranges) dataset previously obtained in clinically healthy, reared rainbow trout Oncorhynchus mykiss (Walbaum, 1792) in order to select the most correlated variables and to test for possible underlying factors explaining the observed correlations among variables as possible physiological status estimates in trout. Moreover, the obtained factors were tested for correlation with widely used indexes, the hepatosomatic and splenosomatic indexes.

\section{Materials and Methods}

This research was conducted on a serum chemistry variables dataset from a previous study, designed to assess normal blood chemistry ranges in rainbow trout. Accordingly, details on sampled fish, fish biometrics, and analytical techniques have been already described [3]. In brief:

\subsection{Experimental Fish}

Forty-five $24 \mathrm{~h}$ fasted rainbow trout (biometrics presented in Table 1) were randomly sampled from a local fish supplier during the same season (end April-middle June). Trout were housed in a raceway fed with well water at approximately constant physicochemical parameters throughout the year. Fish were sampled during regular slaughtering according to European Community regulations (Council Regulation (EC) N. 1099/2009). In particular, fish were stunned by a sharp blow to the head immediately after netting, paying attention to standardize fish sampling, in order to minimize handling stress and the possible occurrence of uncontrolled sources of variation in the tested blood variables. Fish were clinically healthy and underwent complete necropsy to exclude gross pathology and the presence of visible parasites. Moreover, evidence of tissue reaction or damage was ruled out by a microscopic exam of gill filaments, skin and intestinal scrapings, and liver and kidney imprints.

Table 1. Mean and standard error of fish biometrics.

\begin{tabular}{ccc}
\hline & Mean & Std. Error \\
\hline Standard length $(\mathrm{cm})$ & 26.4 & 0.7 \\
Body mass $(\mathrm{g})$ & 254.1 & 20.0 \\
Condition factor & 1.3 & 0.0 \\
Liver mass $(\mathrm{g})$ & 2.8 & 0.2 \\
Hepatosomatic index & 1.2 & 0.1 \\
Splenic mass (g) & 0.6 & 0.1 \\
Splenosomatic index & 0.2 & 0.0 \\
\hline
\end{tabular}

Condition factor (100 body mass standard length $\left.{ }^{-3}\right)$; hepatosomatic index (100 liver mass body mass $\left.{ }^{-1}\right)$; splenosomatic index (100 splenic mass body mass $\left.{ }^{-1}\right)$.

\subsection{Blood Sampling and Analysis}

Blood was collected by caudal venipuncture immediately after stunning, allowed to clot for approximately $10 \mathrm{~min}$, then centrifuged for $10 \mathrm{~min}$ in a refrigerated centrifuge. Hemolyzed samples were discarded. Collected serum was analyzed, using commercially available kits (Olympus Systems Reagents, Olympus Life and Material Science Europe $\mathrm{GmbH}$, Hamburg, Germany) and with an automated biochemical analyzer (Olympus AU400, Mishima Olympus Co. Ltd, Shizuoka, Japan), for the following variables: glucose (GLU), urea (blood urea nitrogen, (BUN)), creatinine (CREA), total bilirubin (TBIL), aspartate aminotransferase (EC 2.6.1.1) (AST), alanine aminotransferase (EC 2.6.1.2) (ALT), alkaline phosphatase (EC 3.1.3.1) (ALP), creatine phosphokinase (EC 2.7.3.2) (CPK), lactate dehydrogenase (EC 1.1.1.27) (LDH), total protein (TPRO), albumin (ALB), triglycerides 
(TRIG), cholesterol (CHOL), Ca, P, and Mg. An ion-selective electrode (ISE) unit on the same analyzer was used to assess serum $\mathrm{Na}, \mathrm{K}$, and $\mathrm{Cl}$.

\subsection{Statistical Analysis}

Serum chemistry variables were preliminarily screened for possible extreme cases by means of a boxplot graph to identify and exclude from analysis cases with values of more than 3 box lengths (interquartile range) from the upper and lower edge of the box. Thirty-nine samples were analyzed further. The mean and standard error for each variable are reported in Table 2.

Table 2. Mean and standard error of serum chemistry variables.

\begin{tabular}{|c|c|c|}
\hline Serum Chemistry Variables & Mean & Std. Error \\
\hline Glucose $\left(\mathrm{mg} \mathrm{dL}^{-1}\right)$ & 116.13 & 10.85 \\
\hline Blood urea nitrogen $\left(\mathrm{mg} \mathrm{dL}^{-1}\right)$ & 4.08 & 0.21 \\
\hline Creatinine $\left(\mathrm{mg} \mathrm{dL}^{-1}\right)$ & 0.30 & 0.01 \\
\hline Total bilirubin $\left(\mathrm{mg} \mathrm{dL}^{-1}\right)$ & 0.04 & 0.00 \\
\hline Albumin $\left(\mathrm{g} \mathrm{dL}^{-1}\right)$ & 1.37 & 0.05 \\
\hline Total protein $\left(\mathrm{g} \mathrm{dL}^{-1}\right)$ & 3.55 & 0.14 \\
\hline Cholesterol (mg dL $\left.{ }^{-1}\right)$ & 249.97 & 10.98 \\
\hline Triglycerides (mg dL $\left.{ }^{-1}\right)$ & 343.38 & 24.35 \\
\hline Aspartate aminotransferase $\left(\mathrm{U} \mathrm{L}^{-1}\right)$ & 435.67 & 25.92 \\
\hline Alanine aminotransferase $\left(\mathrm{U} \mathrm{L}^{-1}\right)$ & 11.44 & 0.82 \\
\hline Alkaline phosphatase $\left(\mathrm{U} \mathrm{L}^{-1}\right)$ & 179.59 & 20.56 \\
\hline Creatine phosphokinase $\left(\mathrm{U} \mathrm{L}^{-1}\right)$ & 1148.64 & 154.90 \\
\hline Lactate dehydrogenase $\left(\mathrm{U} \mathrm{L}^{-1}\right)$ & 2414.31 & 138.03 \\
\hline $\mathrm{Ca}\left(\mathrm{mg} \mathrm{dL}^{-1}\right)$ & 12.32 & 0.20 \\
\hline $\mathrm{P}\left(\mathrm{mg} \mathrm{dL}^{-1}\right)$ & 21.55 & 1.24 \\
\hline $\mathrm{Na}\left(\mathrm{mEq} \mathrm{L}^{-1}\right)$ & 154.51 & 0.83 \\
\hline $\mathrm{K}\left(\mathrm{mEq} \mathrm{L}^{-1}\right)$ & 4.24 & 0.52 \\
\hline $\mathrm{Cl}\left(\mathrm{mEq} \mathrm{L}^{-1}\right)$ & 129.38 & 0.80 \\
\hline
\end{tabular}

Exploratory factor analysis was performed on the resulting dataset, using generalized least squares as the estimation method. The aim of this multivariate method is to reduce data dimensionality and to identify relatively few underlying factors explaining the observed correlations among variables. Furthermore, a lower number of independent factors may be obtained starting from many correlated variables, and the former may be used for subsequent analysis, simplifying the analytical task $[15,16]$. In the present study, the aim was mainly the latter in order to reduce the number of analytical variables, to test for a possible correlation with traditionally widely used biometric indexes (Pearson and Spearman correlation methods), and to develop possible indexes of fish physiological status and general wellness to be adopted in confined, artificial (fish farming) and/or natural systems. SPSS 14.0.1 (SPSS Inc., Chicago, IL, USA) and JASP 0.14.1 [17] were used as statistical packages.

\section{Results}

According to the Kaiser-Meyer-Olkin test results, five serum chemistry variables (ALT, CPK, $\mathrm{Ca}, \mathrm{Na}$, and $\mathrm{Cl}$ ) showed unacceptable sampling adequacy (lower than 0.50, according to Kaiser [18]) and were discarded from further analysis. The overall and relative measure of sampling adequacy is reported in Table 3. It should be stressed that sampling adequacy is a measure of the proportion of variance among variables that might be a common variance to evaluate how data are suited for factor analysis [18]. Therefore, this does not exclude per se the possible clinical diagnostic relevance of the discarded variables. 
Table 3. Kaiser-Meyer-Olkin test results.

\begin{tabular}{cc}
\hline & MSA $^{\mathbf{a}}$ \\
\hline Overall MSA & 0.667 \\
Glucose & 0.593 \\
Blood urea nitrogen & 0.706 \\
Creatinine & 0.550 \\
Total bilirubin & 0.576 \\
Aspartate aminotransferase & 0.702 \\
Alkaline phosphatase & 0.556 \\
Lactate dehydrogenase & 0.545 \\
P & 0.653 \\
Cholesterol & 0.785 \\
Triglycerides & 0.760 \\
Total protein & 0.675 \\
Albumin & 0.674 \\
K & 0.850 \\
\hline
\end{tabular}

${ }^{a}$ Measure of sampling adequacy.

The remaining variables were screened for commonality to evaluate how the percentage of variance of factor was explained by each correlated variable. All the variables showed sufficient commonality.

Three factors were extracted by means of the generalized least squares extraction method, explaining at best the observed correlations among the analyzed serum chemistry variables (Figure 1).

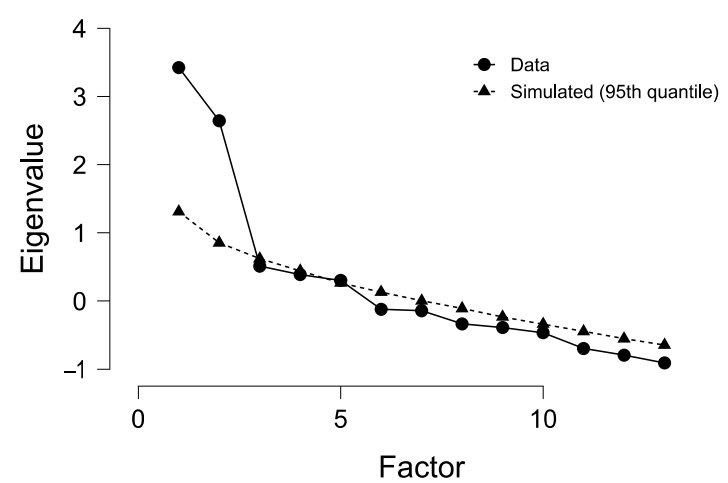

Figure 1. Screen plot. The plot provides information on how much variance in the data, in terms of eigenvalues, is explained by each factor.

The adequacy of the model was tested with the chi-square statistic. The null hypothesis and, as a consequence, the model were not rejected. The orthogonal rotation equamax ensured the best partition of variable correlations among factors. Extracted components and the related explained variance after rotation are reported in Table 4.

Table 4. Factor characteristics ${ }^{\text {a }}$.

\begin{tabular}{cccc}
\hline & Sum of Squared Loadings & Proportion Variance & Cumulative Variance \\
\hline Factor 1 & 3.143 & 0.242 & 0.242 \\
Factor 2 & 2.936 & 0.226 & 0.468 \\
Factor 3 & 1.699 & 0.131 & 0.598 \\
\hline
\end{tabular}

a The applied rotation method is equamax.

The rotated component matrix is reported in Table 5 , where only factor loadings higher than or equal to 0.400 are reported for each extracted factor. 
Table 5. Factor loadings (structure matrix) ${ }^{a, b}$.

\begin{tabular}{|c|c|c|c|}
\hline & Factor 1 & Factor 2 & Factor 3 \\
\hline Glucose & & -0.508 & \\
\hline Blood urea nitrogen & & 0.799 & \\
\hline Creatinine & & & -0.416 \\
\hline Total bilirubin & 0.498 & & \\
\hline Aspartate aminotransferase & & 0.403 & \\
\hline Alkaline phosphatase & & & 0.910 \\
\hline Lactate dehydrogenase & & 0.496 & \\
\hline $\mathrm{P}$ & & 0.880 & \\
\hline Cholesterol & 0.714 & & 0.527 \\
\hline Triglycerides & & & 0.422 \\
\hline Total protein & 0.999 & & \\
\hline Albumin & 0.966 & & \\
\hline K & & 0.745 & \\
\hline
\end{tabular}

a The applied rotation method is equamax. ${ }^{\mathrm{b}}$ Factor loadings higher than or equal to 0.400 and shared by different factors are bolded.

The path diagram shows graphically the loading from each factor on each variable (Figure 2).

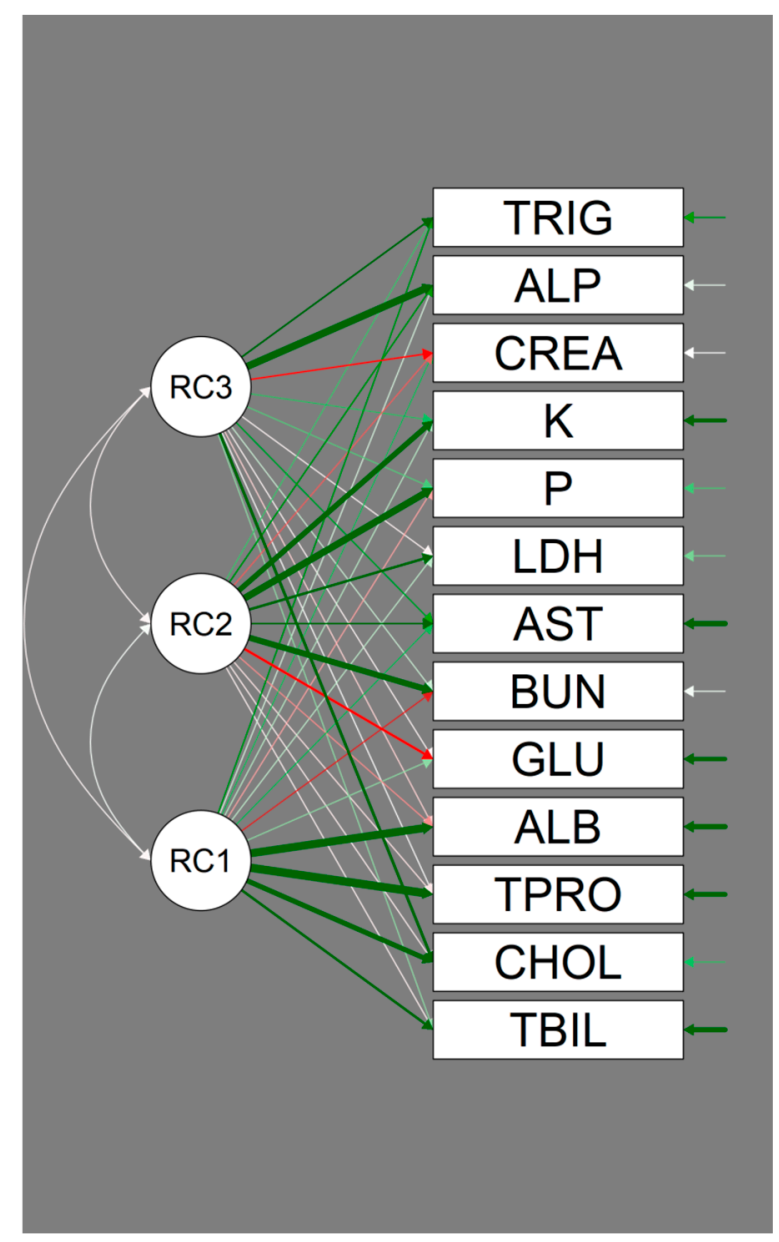

Figure 2. Path diagram. Factors are represented by circles and serum chemistry variables by boxes. The arrows going from the factors to the variables represent the loading from the factor on the variable, with green indicating a positive loading and red a negative loading. The wider the arrows, the higher the loading. Arrows below the set factor loading (0.400) are transparentized. 
Accordingly, TBIL, TPRO, ALB, and CHOL are clearly associated with Factor 1, and the latter result is also associated with Factor 3. GLU, BUN, AST, LDH, P, and K are associated with Factor 2, whereas CREA, ALP, and TRIG are mainly associated with Factor 3, with CHOL being shared with Factor 1, as underlined in Table 5.

The obtained factor scores (factor scores method: regression) correlate negatively with some of the biometric indexes. In particular, Factor 1 correlates with the hepatosomatic index (Spearman's rho, $-0.342 ; p<0.05$ ) and Factors 2 and 3 with the splenosomatic index (respectively, Spearman's rho, -0.322 and $-0.394 ; p<0.05$ ).

\section{Discussion}

All serum variables fell within the normal ranges for rainbow trout, as previously assessed [3].

No direct comparison in terms of confirmatory factor analysis can be made with previous studies because no author has previously applied exploratory factor analysis to a trout serum chemistry dataset. Nevertheless, Wagner et al. [19] performed factor analysis on six multivariate blood chemistry datasets in a related species, Oncorhynchus tshawytscha (Walbaum, 1792). In particular, four underlying factors were obtained: a "nutritional factor," relying on TPRO, CHOL, Ca, and ALP; a "tissue damage factor," relying on ALT, AST, and CPK; a "lipid metabolism factor," relying on triacylglycerol lipase and TRIG; and a "stress factor," relying on cortisol, GLU, $\mathrm{Na}$, and $\mathrm{Cl}$. In the present study, the dataset did not include cortisol and triacylglycerol lipase. Moreover, other substantial differences appeared with regard to the extracted factors (3 vs. 4 factors), the excluded variables (ALT, $\mathrm{CPK}, \mathrm{Na}$, and $\mathrm{Cl}$ ), and the variable partition among factors.

Factor 1 relies, in order of decreasing strength, on TPRO, ALB, CHOL, and TBIL. Furthermore, TRIG should be considered, though their factor loading value of 0.385 was lower than the settled threshold. Albumin is a relatively small fraction of total blood protein in trout, though protein fractions have not been extensively studied compared to mammals [20]. Nevertheless, and apart from a relatively low presence of immunoglobulins (less than $10 \%$ of total protein in healthy fish), the vast majority of blood protein fractions are produced by the liver [1,3,20-22]. Moreover, blood proteins are transporters of cholesterol and lipids in general in the form of liver-synthesized lipoproteins [1,23-27]. Fish lack subcutaneous fat as significant lipid storage, with the liver and/or muscle being deputed to the latter task, according to the species. Very-low-density plasma lipoproteins are reported to reflect where lipids are stored, either in the liver or muscle [26]. With regard to bilirubin, unconjugated bilirubin, the predominant form in physiological conditions, is known to be ligated to albumin in mammals and with a high-density lipoprotein in Oncorhynchus keta (Walbaum, 1792) [1,28,29]. Accordingly, this reflects the relationship between TBIL and TPRO (they showed a strong linear correlation: Pearson's $r, 0.566 ; p<0.01$ ) and, ultimately, Factor 1 .

The hepatosomatic index is an aspecific liver condition index. Given the central role of the liver in fish nutrients and toxin metabolism, it has been used in different studies to test for nutrition state adequacy, liver nutrient/toxin overload, liver nutrient depletion, etc. [13,30-32]. As a result, and given also the correlation of Factor 1 related scores with the hepatosomatic index, the author proposes to consider Factor 1 as a possible protein (liver) metabolism factor.

Factor 2 relies, in order of decreasing strength, on P, BUN, K, GLU, LDH, and AST. Alkaline phosphatase should also be considered, though its factor loading (0.393) was lower than the settled threshold. Phosphorus along with $\mathrm{Ca}$ are the most represented macroelements in vertebrates. Values ranging from 20,500 to $16,700 \mathrm{ppm}$ of wet body mass are reported in Atlantic salmon, according to body mass (respectively, from $<0.3$ to $<1500 \mathrm{~g}$ ), whereas $P$ content increases with the condition factor in rainbow trout [33,34]. Because of its enzymatic action, ALP is closely related to P metabolism, and its correlation was also observed in trout, though blood $\mathrm{P}$ was not considered an optimal indicator of $\mathrm{P}$ status in the latter species [35]. There is concern about $P$ excretion in reared fish and its environmental 
effect, with particular regard to eutrophication [36,37]. Excess P may be released in the blood from the cell cytoplasm and membrane after cell injury, with particular regard to erythrocyte in the course of hemolysis [1].

Ammonia is the principal nitrogen waste in adult teleost fish, and gills are the main route of excretion [38,39]. Nevertheless, there are other nitrogen excretion forms, the most relevant of which is urea. In rainbow trout, ammonia nitrogen accounted for 53 to $68 \%$ of total nitrogen waste and urea nitrogen for 6 to 10\% [38]. Urea is produced by uricolysis and/or arginolysis, though the presence of the ornithine-urea cycle enzymes have been observed in larval trout to account for impaired ammonia excretion caused by the absence of functional gills and the presence of an acellular chorion (egg capsule), limiting organismto-blood diffusion [40]. Interestingly, chronic cortisol elevation was shown to increase BUN concentration and its branchial and renal excretion by threefold [41]. More recently, and interestingly, Clark et al. [42] reported that the genes related to the urea cycle and polyamine synthesis in rainbow trout show dynamic expression responses to inflammation as a possible route of arginine recycling.

Glucose is the most important biological monosaccharide, a privileged or unique energy source for many cell types [43]. The liver has a central role in glucose homeostasis through glucose synthesis and storage. The kidney should also be considered for its contribution to glucose synthesis along with muscle for its contribution to glucose use. Moreover, the intestine, as the first line in nutrient uptake, plays an important role in glucose homeostasis. In trout, similarly to other carnivorous fish, glucose metabolism is somewhat different from typical mammals, relying mainly on gluconeogenesis at hepatic, renal, and intestine levels rather than on food carbohydrate use and glycogenolysis [44,45]. One of the most important physiological causes of blood glucose rise in mammals is excitement and stress [1]. Trout showed a reduced stress response compared to other less domesticated fish (e.g., Eurasian perch (Perca fluviatilis Linnaeus, 1758)), particularly in repeatedly stressed exemplars [46]. Nevertheless, stress causes blood cortisol and glucose to increase, stressing the need to standardize the sampling strategy in order to mitigate its possible impact.

Aspartate aminotransferase is a cytoplasmic and mitochondrial enzyme, catalyzing the deamination of aspartate to form oxaloacetate. Lactic dehydrogenase is a cytoplasmic enzyme, catalyzing the conversion of pyruvate to lactate. The main cellular sources of serum AST and LDH activity are liver cells, skeletal muscle cells, cardiac muscle cells, and erythrocytes [1]. Aspartate aminotransferase and lactate dehydrogenase isozymes have been reported in brown trout (Salmo trutta Linnaeus, 1758), respectively, in the liver, muscle, and eye (AST) and in the liver, muscle, heart, kidney, eye (LDH) [47]. Lactate dehydrogenase polymorphism was reported in rainbow trout, with subunits in the liver and gill [48].

Cell damage is the major mechanism leading to increased AST and LDH serum activity. Regarding ALP, induction is considered the main cause of increased serum activity, according to species. In mammals, different ALP isoforms are known, from the liver, bone, intestine, mammary gland; therefore, the main cellular sources of serum ALP are liver cells, biliary epithelial cells, osteoblasts, and mammary gland cells. Bone, liver, and intestine isoforms are reported in rainbow trout $[35,49]$. In fish, another isoform is reported from the skin and epidermal mucus, with possible anti-inflammatory and innate immunity function, showing a correlation with serum ALP activity [50].

Cytosolic (e.g., ALT, LDH) and membrane enzymes (e.g., ALP) may be released in the blood by reversible or irreversible cell damage, comprising membrane blebbing, increased membrane permeation, or necrosis. Mitochondrial enzymes (e.g., AST) need more severe tissue damage to be released $[1,51,52]$. It should be stressed that serum enzyme activity in clinically healthy organisms is assumed to result from physiologic cellular turnover [1]. Moreover, the transitory elevation of the activity of some serum enzymes over normal ranges may result as a consequence of intense physical exercise, without any pathological consequence for the individual $[53,54]$. The effect of the temperature at which enzyme 
activity is analyzed $\left(37^{\circ} \mathrm{C}\right.$ is the internationally accepted reference temperature) should be taken into account too, in particular when poikilothermic vertebrates, like fish, are studied [3].

Potassium, along with $\mathrm{Na}$, is one of the most representative monovalent cations. Because of the $\mathrm{Na} / \mathrm{K}$ pump action, it is mainly intracellular, though it flows extracellularly during cell membrane repolarization $[43,55]$. Moreover, its transmembrane movement is related to $\mathrm{H}^{+}$movement, in the regulation of blood $\mathrm{pH}$, and to cell volume $[1,56,57]$. Therefore, an increase in serum $\mathrm{K}$ concentration may be due to morphofunctional membrane alteration, cell lysis, in particular hemolysis, inorganic acidosis, and renal insufficiency or failure $[1,56]$.

Based upon the aforementioned considerations, the author proposes to consider Factor 2 as a possible cell turnover factor.

Factor 3 relies, in order of factor loading, on ALP, CHOL, TRIG, and CREA. Very interestingly, in lymph ALP, an increase is reported in response to lipid feeding, possibly stimulated by the uptake and/or the re-esterification of lipid digestion products [58]. Moreover, its involvement in chylomicron formation and fatty acid metabolism has been suggested [59], and its possible involvement in cholesterol metabolism has been recently proposed [60], linking ALP with CHOL and TRIG. Plasma lipoproteins have been characterized in rainbow trout according to age, sex, and season. Referring to human clinical standards, trout may be considered hyperlipidemic and hyperlipoproteinemic; moreover, the apolipoprotein compositions, according to each lipoprotein class, and their similitude with human counterparts have been described [61]. In trout, high-density lipoproteins (HDLs) are catabolized mainly in the kidney, stressing the key role of the latter in the endocytosis of exogenous and endogenous macromolecules [62]. Conversely, native lowdensity lipoproteins (LDLs) are catabolized mainly in the liver, though modified LDLs are cleared by a scavenger receptor pathway in the kidney [63,64]. Creatinine derives from muscular creatine degradation and is cleared by glomerular filtration in the kidney and by the alimentary canal. Differently from urea, it is not resorbed by renal tubules, accounting for the glomerular filtration rate [1]. Because fish rely mainly on gills for excretion, there is a generalized lack of information about renal CREA clearance in fish [65]. Apart from altered clearance, CREA may increase as a consequence of muscle damage, including intense agonist activity [1]. Recently, a blood CREA increase has been related to muscle activity in trout [4]. Moreover, muscle, along with visceral adipose tissue and the liver, is also involved in lipid metabolism. In particular, trout, as a "fatty fish," has a relatively low amount of hepatic lipid storage and, conversely, is able to store a significant level of lipid in its musculature to be used particularly during endurance swimming and to be mobilized during starvation $[66,67]$.

Referring to previous considerations, Factor 3 can be considered as a lipid (muscle) metabolism factor.

With regard to the negative correlation between Factors 2 and 3 with the splenosomatic index, the latter has been used as a rough estimate of immunocompetence, with a higher value associated with immune activation [68]. Moreover, spleen mass is affected by acute stress. In particular, acute spleen mass reduction is observed either as a result of the massive release of erythrocytes into the bloodstream or as a result of leukocyte glucocorticoidmediated activation, recruitment, and tissue redistribution [69-72]. The widely known lymphocyte glucocorticoid-induced apoptosis [73] should also be considered as a possible source of variation in spleen mass. Assuming the implication of physiological stress (eustress) in the modulation of Factor 2, a possible conflicting result emerges with regard to glucose, which contributes negatively to the loading of the previous factor and correlates the latter negatively with the splenosomatic index. Nevertheless, the immune system relies strongly on blood glucose [74], thus its availability may correspond to a rather competent immune system and consequently to an increased splenosomatic index. With regard to the negative factor loading of CREA, admitting its possible marker function of muscle activity, it may be related to an immunomodulating effect of exercise, as reported in humans, in 
which moderate and regular exercise is associated with immunostimulation, whereas strenuous exercise may cause temporary immunodepression [75]. With regard to lipids, their qualitative and/or quantitative variation has proven immunomodulating activity also in trout [76,77]. This aspect highlights the possible role of CHOL and TRIG in Factor 3, particularly the correlation of this latter with the splenosomatic index. As a consequence, both Factors 2 and 3 may account for trout immunocompetence, deserving nevertheless further research and definitive confirmation using specific and aspecific immunological markers and controlling for possible confounding factors able to affect spleen mass.

\section{Conclusions}

The exploratory factor analysis of 18 serum chemistry variables resulted in the selection of 13 highly correlated variables. Moreover, three underlying factors were identified that explained the observed correlations among variables, the scores of which correlated negatively with some traditionally used biometric indexes, such as the hepatosomatic (Factor 1) and splenosomatic indexes (Factors 2 and 3).

Because factor analysis is an exploratory analysis, the aim of which is to reduce data dimensionality and to identify relatively few underlying factors explaining the observed correlations among variables, factors have been tentatively associated with: protein (liver) metabolism (Factor 1), cell turnover (Factor 2), lipid (muscle) metabolism (Factor 3).

Further research is warranted for a definitive confirmation of the physiological significance and for the validation of the described underlying factors in order to adopt them in the assessment of trout physiological status and general wellness both in confined, artificial, and/or natural systems.

Funding: This research received no external funding.

Institutional Review Board Statement: Ethical review and approval were waived for this study, because fish were sampled during regular slaughtering for human consumption according to European Community regulations (Council Regulation (EC) N. 1099/2009).

Informed Consent Statement: Not applicable.

Conflicts of Interest: The authors declare no conflict of interest.

\section{References}

1. Stockham, S.L.; Scott, M.A. Fundamentals of Veterinary Clinical Pathology, 2nd ed.; Blackwell Publishing: Oxford, UK, 2008.

2. Groff, J.M.; Zinkl, J.G. Hematology and clinical chemistry of cyprinid fish. Common carp and goldfish. Vet. Clin. N. Am. Exot. Anim. Pract. 1999, 2, 741-776. [CrossRef]

3. Manera, M.; Britti, D. Assessment of blood chemistry normal ranges in rainbow trout. J. Fish Biol. 2006, 69, 1427-1434. [CrossRef]

4. Pastorino, P.; Bergagna, S.; Dezzutto, D.; Barbero, R.; Righetti, M.; Pagliasso, G.; Gasco, L.; Gennero, M.S.; Pizzul, E.; Dondo, A.; et al. Long-term assessment of baseline blood biochemistry parameters in rainbow trout (Oncorhynchus mykiss) maintained under controlled conditions. Animals 2020, 10, 1466. [CrossRef]

5. Walsh, P.J.; Mommsen, T.P. Evolutionary considerations of nitrogen metabolism and excretion. In Fish Physiology. Nitrogen Excretion; Wright, P., Anderson, P., Eds.; Academic Press: New York, NY, USA, 2001; Volume 20, pp. 1-30.

6. Ip, Y.K.; Chew, S.F.; Randall, D.J. Ammonia toxicity, tolerance, and excretion. In Fish Physiology. Nitrogen Excretion; Wright, P., Anderson, P., Eds.; Academic Press: New York, NY, USA, 2001; Volume 20, pp. 109-148.

7. Wright, P.A. Nitrogen excretion: Three end products, many physiological roles. J. Exp. Biol. 1995, 198, $273-281$.

8. Aboul Mahasen, L.M. Evolution of the Kidney. Anat. Physiol. Biochem. 2016, 1. [CrossRef]

9. Beyenbach, K.W. Kidneys sans glomeruli. Am. J. Physiol. Ren. Physiol. 2004, 286, 811-827. [CrossRef]

10. Hall, P.; Cash, J. What is the real function of the Liver "Function" tests? Ulster Med. J. 2012, 81, 30-36.

11. Gowda, S.; Desai, P.B.; Kulkarni, S.S.; Hull, V.V.; Math, A.A.K.; Vernekar, S.N. Markers of renal function tests. N. Am. J. Med. Sci. 2010, 2, 170-173. [PubMed]

12. Toni, M.; Manciocco, A.; Angiulli, E.; Alleva, E.; Cioni, C.; Malavasi, S. Review: Assessing fish welfare in research and aquaculture, with a focus on European directives. Animal 2019, 13, 161-170. [CrossRef] [PubMed]

13. Manera, M. I Biomarcatori nel Monitoraggio Ambientale Pesci Ossei ed Ecosistemi Acquatici; Aracne: Rome, Italy, 2013; ISBN 978-88548-6221-0. 
14. Sprague, J.; Bayraktaroglu, L.; Clements, D.; Conlin, T.; Fashena, D.; Frazer, K.; Haendel, M.; Howe, D.G.; Mani, P.; Ramachandran, S.; et al. The Zebrafish Information Network: The zebrafish model organism database. Nucleic Acids Res. 2006, 34, D581-D585. [CrossRef]

15. Suhr, D.D. Principal component analysis vs. exploratory factor analysis. In Proceedings of the SAS Users Group International 30, Philadelphia, PA, USA, 10-13 April 2005; pp. 1-11.

16. Joliffe, J.T. Principal Components Analysis, 2nd ed.; Springer: New York, NY, USA, 2002; ISBN 9780080448947.

17. JASP Team. JASP, Version 0.14.1; [Computer Software] 2020. Available online: https://jasp-stats.org/faq/how-do-i-cite-jasp/ (accessed on 29 January 2021).

18. Kaiser, H.F. An index of factorial simplicity. Psychometrika 1974, 39, 31-36. [CrossRef]

19. Wagner, T.; Congleton, J.L. Blood chemistry correlates of nutritional condition, tissue damage, and stress in migrating juvenile chinook salmon (Oncorhynchus tshawytscha). Can. J. Fish. Aquat. Sci. 2004, 61, 1066-1074. [CrossRef]

20. Manera, M.; Britti, D. Assessment of serum protein fractions in rainbow trout using automated electrophoresis and densitometry. Vet. Clin. Pathol. 2008, 37, 452-456. [CrossRef] [PubMed]

21. Olesen, N.; Jørgensen, P. Quantification of serum immunoglobulin in rainbow trout Salmo gairdneri under various environmental conditions. Dis. Aquat. Organ. 1985, 1, 183-189. [CrossRef]

22. Evans, D.H.; Claiborne, J.B.; Currie, S. (Eds.) The Physiology of Fishes, 4th ed.; CRC Press: Boca Raton, FL, USA, 2014; ISBN 9781439880319.

23. Yeganeh, S.; Teimouri, M.; Amirkolaie, A.K. Dietary effects of Spirulina platensis on hematological and serum biochemical parameters of rainbow trout (Oncorhynchus mykiss). Res. Vet. Sci. 2015, 101, 84-88. [CrossRef] [PubMed]

24. Farrell, A.P.; Munt, B. Cholesterol levels in the blood of Atlantic salmonids. Comp. Biochem. Physiol. Part A Physiol. 1983, 75, 239-242. [CrossRef]

25. Javed, M.; Usmani, N. Stress response of biomolecules (carbohydrate, protein and lipid profiles) in fish Channa punctatus inhabiting river polluted by Thermal Power Plant effluent. Saudi J. Biol. Sci. 2015, 22, 237-242. [CrossRef]

26. Ando, S.; Mori, Y. Characteristics of Serum Lipoprotein Features Associated with Lipid Levels of Muscle and Liver from Five Species of Fish. Nippon Suisan Gakkaishi 1993, 59, 1565-1571. [CrossRef]

27. Babin, P.J.; Vernier, J.M. Plasma lipoproteins in fish. J. Lipid Res. 1989, 30, 467-489. [CrossRef]

28. Ando, S.; Hatano, M. Bilirubin-binding protein in the serum of spawning-migrating chum salmon, Oncorhynchus keta: Its identity with carotenoid-carrying lipoprotein. Fish Physiol. Biochem. 1988, 5, 69-78. [CrossRef]

29. Ahlfors, C.E.; Wennberg, R.P. Bilirubin-albumin binding and neonatal jaundice. Semin. Perinatol. 2004, 28, 334-339. [CrossRef] [PubMed]

30. Boujard, T.; Leatherland, J.F. Circadian pattern of hepatosomatic index, liver glycogen and lipid content, plasma non-esterified fatty acid, glucose, T3, T4, growth hormone and cortisol concentrations in Oncorhynchus mykiss held under different photoperiod regimes and fed using demand. Fish Physiol. Biochem. 1992, 10, 111-122. [CrossRef]

31. Al-Ghais, S.M. Acetylcholinesterase, glutathione and hepatosomatic index as potential biomarkers of sewage pollution and depuration in fish. Mar. Pollut. Bull. 2013, 74, 183-186. [CrossRef] [PubMed]

32. Bolger, T.; Connolly, P.L. The selection of suitable indices for the measurement and analysis of fish condition. J. Fish. Biol. 1989, 34, 171-182. [CrossRef]

33. Shearer, K.D.; ÅSgård, T.; Andorsdöttir, G.; Aas, G.H. Whole body elemental and proximate composition of Atlantic salmon (Salmo salar) during the life cycle. J. Fish. Biol. 1994, 44, 785-797. [CrossRef]

34. Rønsholdt, B. Effect of size/age and feed composition on body composition and phosphorus content of rainbow trout, Oncorhynchus mykiss. Water Sci. Technol. 1995, 31, 175-183. [CrossRef]

35. Skonberg, D.I.; Yogev, L.; Hardy, R.W.; Dong, F.M. Metabolic response to dietary phosphorus intake in rainbow trout (Oncorhynchus mykiss). Aquaculture 1997, 157, 11-24. [CrossRef]

36. Coloso, R.M.; King, K.; Fletcher, J.W.; Hendrix, M.A.; Subramanyam, M.; Weis, P.; Ferraris, R.P. Phosphorus utilization in rainbow trout (Oncorhynchus mykiss) fed practical diets and its consequences on effluent phosphorus levels. Aquaculture 2003, 220, 801-820 [CrossRef]

37. Asmala, E.; Saikku, L. Closing a loop: Substance flow analysis of nitrogen and phosphorus in the rainbow trout production and domestic consumption system in Finland. Ambio 2010, 39, 126-135. [CrossRef]

38. Kajimura, M.; Croke, S.J.; Glover, C.N.; Wood, C.M. Dogmas and controversies in the handling of nitrogenous wastes: The effect of feeding and fasting on the excretion of ammonia, urea and other nitrogenous waste products in rainbow trout. J. Exp. Biol. 2004, 207, 1993-2002. [CrossRef]

39. Altinok, I.; Grizzle, J.M. Excretion of ammonia and urea by phylogenetically diverse fish species in low salinities. Aquaculture 2004, 238, 499-507. [CrossRef]

40. Wright, P.A.; Felskie, A.; Anderson, P.M. Induction of ornithine-urea cycle enzymes and nitrogen metabolism and excretion in rainbow trout (Oncorhynchus mykiss) during early life stages. J. Exp. Biol. 1995, 198, 127-135.

41. McDonald, M.D.; Wood, C.M. The effect of chronic cortisol elevation on urea metabolism and excretion in the rainbow trout (Oncorhynchus mykiss). J. Comp. Physiol. B Biochem. Syst. Environ. Physiol. 2004, 174, 71-81. [CrossRef]

42. Clark, T.C.; Tinsley, J.; Macqueen, D.J.; Martin, S.A.M. Rainbow trout (Oncorhynchus mykiss) urea cycle and polyamine synthesis gene families show dynamic expression responses to inflammation. Fish Shellfish Immunol. 2019, 89, 290-300. [CrossRef] 
43. Nelson, D.L.; Cox, M.M. Lehninger Principles of Biochemistry, 5th ed.; W. H. Freeman and Company: New York, NY, USA, 2008; ISBN 9788578110796.

44. Kirchner, S.; Panserat, S.; Lim, P.L.; Kaushik, S.; Ferraris, R.P. The role of hepatic, renal and intestinal gluconeogenic enzymes in glucose homeostasis of juvenile rainbow trout. J. Comp. Physiol. B Biochem. Syst. Environ. Physiol. 2008, 178, 429-438. [CrossRef]

45. Polakof, S.; Álvarez, R.; Soengas, J.L. Gut glucose metabolism in rainbow trout: Implications in glucose homeostasis and glucosensing capacity. Am. J. Physiol. Regul. Integr. Comp. Physiol. 2010, 299, R19-R32. [CrossRef] [PubMed]

46. Jentoft, S.; Aastveit, A.H.; Torjesen, P.A.; Andersen, Ø. Effects of stress on growth, cortisol and glucose levels in non-domesticated Eurasian perch (Perca fluviatilis) and domesticated rainbow trout (Oncorhynchus mykiss). Comp. Biochem. Physiol. A Mol. Integr. Physiol. 2005, 141, 353-358. [CrossRef] [PubMed]

47. Allendrof, F.W.; Mithcell, N.; Ryman, N.; Ståhl, G. Isozyme loci in brown trout (Salmo trutta L.): Detection and interpretation from population data. Hereditas 1977, 86, 179-189. [CrossRef]

48. Williscroft, S.N.; Tsuyuki, H. Lactate dehydrogenase systems of rainbow trout-Evidence for polymorphism in liver and additional subunits in gills. J. Fish. Res. Board Can. 1970, 27, 1563-1567. [CrossRef]

49. Matusiewicz, M.; Dabrowski, K. Utilization of the bone/liver alkaline phosphatase activity ratio in blood plasma as an indicator of ascorbate deficiency in salmonid fish. Proc. Soc. Exp. Biol. Med. 1996, 212, 44-51. [CrossRef] [PubMed]

50. Lallès, J.P. Biology, environmental and nutritional modulation of skin mucus alkaline phosphatase in fish: A review. Fish Shellfish Immunol. 2019, 89, 179-186. [CrossRef]

51. Murphy, M.P.; Hohl, C.; Brierley, G.P.; Altschuld, R.A. Release of enzymes from adult rat heart myocytes. Circ. Res. 1982, 51, 560-568. [CrossRef] [PubMed]

52. Ramaiah, S.K. A toxicologist guide to the diagnostic interpretation of hepatic biochemical parameters. Food Chem. Toxicol. 2007, 45, 1551-1557. [CrossRef]

53. Sjogren, M.H. Transaminase levels and vigorous exercise. Gastroenterol. Hepatol. 2007, 3, 913-914.

54. Pettersson, J.; Hindorf, U.; Persson, P.; Bengtsson, T.; Malmqvist, U.; Werkström, V.; Ekelund, M. Muscular exercise can cause highly pathological liver function tests in healthy men. Br. J. Clin. Pharmacol. 2008, 65, 253-259. [CrossRef]

55. Karp, G. Cell and Molecular Biology; John Wiley \& Sons, Inc.: Hoboken, NJ, USA, 2010.

56. Landowne, D. Cell Physiology; Lange Mecial Books/McGraw-Hill: New York, NY, USA, 2006; ISBN 0071491694.

57. DiBartola, S.P. Fluid, Electolyte and Acid-Base Disorders in Small Animals, 4th ed.; Elsevier Saunders: St. Louis, MI, USA, 2012; ISBN 9781437706543.

58. Nauli, A.M.; Zheng, S.; Yang, Q.; Li, R.; Jandacek, R.; Tso, P. Intestinal alkaline phosphatase release is not associated with chylomicron formation. Am. J. Physiol. Gastrointest. Liver Physiol. 2003, 284, G583-G587. [CrossRef]

59. Nakano, T.; Shimanuki, T.; Matsushita, M.; Koyama, I.; Inoue, I.; Katayama, S.; Alpers, D.H.; Komoda, T. Involvement of intestinal alkaline phosphatase in serum apolipoprotein B-48 level and its association with ABO and secretor blood group types. Biochem. Biophys. Res. Commun. 2006, 341, 33-38. [CrossRef] [PubMed]

60. Takeuchi, A.; Hisamatsu, K.; Okumura, N.; Sugimitsu, Y.; Yanase, E.; Ueno, Y.; Nagaoka, S. IIAEK targets intestinal alkaline phosphatase (IAP) to improve cholesterol metabolism with a specific activation of IAP and downregulation of abca1. Nutrients 2020, 12, 2859. [CrossRef] [PubMed]

61. Wallaert, C.; Babin, P.J. Age-related, sex-related, and seasonal changes of plasma lipoprotein concentrations in trout. J. Lipid Res. 1994, 35, 1619-1633. [CrossRef]

62. Gjøen, T.; Berg, T. Metabolism of high-density lipoproteins in rainbow trout. Biochim. Biophys. Acta Lipids Lipid Metab. 1992, 1125, 8-12. [CrossRef]

63. Gjøen, T.; Berg, T. Metabolism of low density lipoproteins in rainbow trout. Fish. Physiol. Biochem. 1992, 9, 453-461. [CrossRef]

64. Frøystad, M.K.; Volden, V.; Berg, T.; Gjøen, T. Metabolism of oxidized and chemically modified low density lipoproteins in rainbow trout Clearance via scavenger receptors. Dev. Comp. Immunol. 2002, 26, 723-733. [CrossRef]

65. Wood, C.M. Influence of feeding, exercise, and temperature on nitrogen metabolism and excretion. Fish. Physiol. 2001, 20, 201-238.

66. Lutfi, E.; Gong, N.; Johansson, M.; Sánchez-Moya, A.; Björnsson, B.T.; Gutiérrez, J.; Navarro, I.; Capilla, E. Breeding selection of rainbow trout for high or low muscle adiposity differentially affects lipogenic capacity and lipid mobilization strategies to cope with food deprivation. Aquaculture 2018, 495, 161-171. [CrossRef]

67. Johansson, M.; Morgenroth, D.; Einarsdottir, I.E.; Gong, N.; Björnsson, B.T. Energy stores, lipid mobilization and leptin endocrinology of rainbow trout. J. Comp. Physiol. B Biochem. Syst. Environ. Physiol. 2016, 186, 759-773. [CrossRef]

68. Hadidi, S.; Glenney, G.W.; Welch, T.J.; Silverstein, J.T.; Wiens, G.D. Spleen size predicts resistance of rainbow trout to flavobacterium psychrophilum challenge. J. Immunol. 2008, 180, 4156-4165. [CrossRef]

69. Milla, S.; Mathieu, C.; Wang, N.; Lambert, S.; Nadzialek, S.; Massart, S.; Henrotte, E.; Douxfils, J.; Mélard, C.; Mandiki, S.N.M.; et al. Spleen immune status is affected after acute handling stress but not regulated by cortisol in Eurasian perch, Perca fluviatilis. Fish Shellfish Immunol. 2010, 28, 931-941. [CrossRef]

70. Pearson, M.P.; Stevens, E.D. Size and hematological impact of the splenic erythrocyte reservoir in rainbow trout, Oncorhynchus mykiss. Fish Physiol. Biochem. 1991, 9, 39-50. [CrossRef] [PubMed]

71. Acerete, L.; Balasch, J.C.; Espinosa, E.; Josa, A.; Tort, L. Physiological responses in Eurasian perch (Perca fluviatilis, L.) subjected to stress by transport and handling. Aquaculture 2004, 237, 167-178. [CrossRef] 
72. Maule, A.G.; Schreck, C.B. Changes in numbers of leukocytes in immune organs of juvenile coho salmon after acute stress or cortisol treatment. J. Aquat. Anim. Health 1990, 2, 298-304. [CrossRef]

73. Planey, S.L.; Litwack, G. Glucocorticoid-induced apoptosis in lymphocytes. Biochem. Biophys. Res. Commun. 2000, 279, 307-312. [CrossRef]

74. Kvidera, S.K.; Horst, E.A.; Mayorga, E.J.; Sanz-Fernandez, M.V.; Abuajamieh, M.; Baumgard, L.H. Estimating glucose requirements of an activated immune system in growing pigs. J. Anim. Sci. 2017, 95, 5020-5029. [CrossRef] [PubMed]

75. Gleeson, M. Immune function in sport and exercise. J. Appl. Physiol. 2007, 103, 693-699. [CrossRef] [PubMed]

76. Hubler, M.J.; Kennedy, A.J. Role of lipids in the metabolism and activation of immune cells. J. Nutr. Biochem. $2016,34,1-7$. [CrossRef] [PubMed]

77. Kiron, V.; Fukuda, H.; Takeuchi, T.; Watanabe, T. Essential fatty acid nutrition and defence mechanisms in rainbow trout Oncorhynchus mykiss. Comp. Biochem. Physiol. Part A Physiol. 1995, 111, 361-367. [CrossRef] 